\title{
Studies on Association, Path Analysis and Genetic Parameters for Seed Cotton Yield and It's Contributing Characters in Desi Cotton (Gossypium arboreum L.)
}

\author{
Sunayana $^{*}$, R.S. Sangwan and Somveer Nimbal \\ Department of Genetics and Plant Breeding, CCS Haryana Agricultural University, \\ Hisar-125 004, Haryana, India \\ *Corresponding author
}

\begin{tabular}{|c|c|}
\hline \multicolumn{2}{|r|}{ A B S T R A C T } \\
\hline & \multirow{6}{*}{$\begin{array}{l}\text { The research work comprising of genetic variability, heritability and genetic advance as } \\
\text { well as correlation and path analysis study for } 12 \text { quantitative traits in three genotypes of } \\
\text { cotton (Gossypium arboreum L.) was carried out during } 2015 \text { and } 2016 \text { at Research Farm } \\
\text { of Cotton Section, Department of Genetics and Plant Breeding, CCS Haryana Agricultural } \\
\text { University, Hisar, India. The genotypic differences were significant for all the traits except } \\
\text { number of monopods/plant and number of seeds/boll. The variability studies indicated that } \\
\text { high PCV and GCV were observed for seed cotton yield per plant, lint yield per plant and } \\
\text { number of bolls per plant. Seed cotton yield per plant, lint yield per plant, number of bolls } \\
\text { per plant and days to first flower shows high heritability with high genetic advance over } \\
\text { mean. The correlation study revealed that seed cotton yield was found to be positively and } \\
\text { significantly correlated with traits viz. lint yield per plant, number of bolls per plant, boll } \\
\text { weight, seed index, number of seeds per boll, number of monopods per plant, plant height, } \\
\text { days to boll bursting and days to first flower. Path analysis revealed that lint yield per plant } \\
\text { exhibited maximum positive direct effect on seed cotton yield followed by number of bolls } \\
\text { per plant, seed index, boll weight and plant height. Hence selection for these traits would } \\
\text { be quite effective to improve the seed cotton yield. }\end{array}$} \\
\hline Keywords & \\
\hline & \\
\hline Ar & \\
\hline & \\
\hline & \\
\hline
\end{tabular}

\section{Introduction}

Cotton is a crop of prosperity having a profound influence on men and matter. Cotton is one of the most important commercial crops and popularly known as the "White Gold". It is an industrial commodity of worldwide importance. India has been the traditional home of cotton and cotton textiles. It occupies the place of pride in Indian agriculture and economy by earning valuable foreign exchange. Four out of the 50 recognized cotton species in the world are cultivated. In India, all the four cultivated cotton species viz., Gossypium arboreum, $G$. herbaceum, G. hirsutum and G. barbadense are grown on a commercial scale. Genetic variability is pre-requisite for plant breeders to exercise selection. The phenotypic and genotypic coefficients of variation were estimated using genotypic and phenotypic variances respectively. The coefficient of variation indicated only the extent of existing variability for various traits, but does not give any information about the heritable portion of it. Therefore, heritability accompanied by 
estimates of genetic advance and genetic advance as per cent mean were also estimated. Heritability itself provides no indication about the genetic progress that would result from selection. However, at a fixed selection pressure, the amount of advance varies with magnitude of heritability. Genetic advance in a population cannot be predicted from heritability alone. Many investigations had studied heritability for seed cotton yield and other traits (Basbag and Gencer, 2004; Basal and Turgut, 2005; Khurram et al., 2009; Dhamayanathi et al., 2010). Further, efficiency of selection in any breeding programme mainly depends upon the knowledge of association of the characters. Phenotypic correlation indicated the extent of the relation between two characters while genotypic correlation provides an estimate of inherent association between the genes controlling them. The cause for negative effect of the trait is very essential for formulating selection indices by path analysis (Sambamurthy et al., 1995; Amudha et al., 1996; Sambamurthy and Rao, 1998; Rao, et al., 2001; Kaushik, et al., 2003; Gururajan and Sunder, 2004; Gite et al., 2006). Hence the present study was planned to assess the variability, correlation and path analysis for various yield and yield contributing characters in a set of genotypes. Such information may be fruitful in formulating efficient selection programme for synthesis and development of new cotton genotypes with improved yield and its contributing traits.

\section{Materials and Methods}

The study was conducted at the Research Farm of Cotton Section, Department of Genetics and Plant Breeding, Chaudhary Charan Singh Haryana Agricultural University, Hisar. It is situated in the semiarid zone at an elevation of $215.2 \mathrm{~m}$ with a longitude of $75^{\circ} 46^{\prime} \mathrm{E}$ and latitude of
$29^{0} 10^{\prime} \mathrm{N}$. The experimental material for the present study comprised of 3 varieties of desi cotton i.e. HD123, HD 324 and HD 432. All the experimental material was grown in six environments (Table 1) which comprised of two years (2015 and 2016) and three different sowing times (early, normal and late). All the varieties were grown in a randomized block design (RBD) with six replications. There were eight rows of each genotype of six meter length, rows were spaced $67.5 \mathrm{~cm}$ apart and plant to plant distance was kept $30 \mathrm{~cm}$. At the time of square initiation five competitive plants were tagged from each treatment and replication for taking the observations for days to first flower, days to boll bursting, plant height $(\mathrm{cm})$, number of monopods per plant, number of bolls per plant, boll weight $(\mathrm{g})$, number of seeds per boll, ginning out turn (\%), seed cotton yield per plant (g), lint yield per plant $(\mathrm{g})$, seed index $(\mathrm{g})$ and lint index $(\mathrm{g})$.

Genotypic and phenotypic coefficient of variation was calculated using the method suggested by Burton and de-vane (1953). Heritability in broad sense was calculated by the method of Hanson et al., (1956) and genetic advance was categorized based on reports of Johanson et al., (1955). Correlation coefficients at phenotypic and genotypic level were calculated as per procedure given by AlJibouri et al., (1958). Path analysis was carried out as suggested by Dewey and Lu (1959), respectively.

\section{Results and Discussion}

Analysis of variance revealed significant differences among all genotypes for all the traits except number of monopods/plant and number of seeds/boll. Estimates of genetic variability (Table 2.) revealed high estimate of phenotypic coefficient of variation (PCV) and genotypic coefficient of variation (GCV) for seed cotton yield per plant $(27.89 \%$ and $25.63 \%)$, lint yield per plant $(27.87 \%$ and 
$25.34 \%$ ) and number of bolls per plant $(20.76 \%$ and $19.21 \%)$ whereas, moderate estimates of PCV and GCV were estimated for traits like days to first flower $(11.93 \%$ and $11.59 \%)$, plant height (15.04\% and $10.35 \%)$, boll weight $(9.21 \%$ and $8.56 \%)$, number of monopods per plant $(12.19 \%$ and $10.78 \%)$ and lint index (10.25\% and 9.27\%). Days to boll bursting, number of seeds per boll, seed index and ginning outturn exhibited low PCV and GCV of $5.45 \%$ and $4.92 \%, 6.77 \%$ and $5.94 \%, 6.12 \%$ and $4.84 \%, 4.35 \%$ and $4.06 \%$, respectively, indicated that characters were highly influenced by environmental factors (Fig. 1). The phenotypic co- efficient of variation which measures total variation was found to be greater than genotypic coefficient of variation for all the characters indicated some degree of environmental influence on the traits. Selection for improvement of such traits may sometimes be misleading. These findings were also supported by Patnaik and Sial (2010) and Kulkarni et al., (2011). The estimates of high heritability value was noticed in for characters like days to first flower (94.52\%), boll weight (86.39\%), number of bolls per plant $(85.63 \%)$, seed cotton yield per plant $(84.44 \%)$, lint yield per plant $(82.67 \%)$, lint inex $(81.75 \%)$, days to boll bursting $(81.52 \%)$, ginning out turn $(81.10 \%)$, seed index $(80.66 \%)$ and number of seeds per boll $(76.86 \%)$,. These findings were in accordance with previous reports by Joshi et al., (2006). High heritability and high genetic advance over the mean was observed in case of seed cotton yield per plant, lint yield per plant, number of bolls per plant and days to first flower. It indicated that most likely the heritability is due to additive gene effect and selection will be effective for these traits. Similar findings were observed by Neelam and Potdukhe (2002).

Table.1 Description of environments

\begin{tabular}{|l|l|l|l|}
\hline Environment & Date of Sowing & $\begin{array}{l}\text { Environment } \\
\text { Designation }\end{array}$ \\
\hline Year & Sowing period & & \\
\hline \multirow{4}{*}{2015} & Early season & $10-04-2015$ & $\mathrm{E}_{1}$ \\
\cline { 2 - 4 } & Normal season & $15-05-2015$ & $\mathrm{E}_{2}$ \\
\cline { 2 - 4 } & Late season & $5-06-2015$ & $\mathrm{E}_{3}$ \\
\hline \multirow{3}{*}{2016} & Early season & $26-04-2016$ & $\mathrm{E}_{4}$ \\
\cline { 2 - 4 } & Normal season & $5-05-2016$ & $\mathrm{E}_{5}$ \\
\cline { 2 - 4 } & Late season & $2-06-2016$ & $\mathrm{E}_{6}$ \\
\hline
\end{tabular}

Table.2 Genetic components of variance for various quantitative traits

\begin{tabular}{|c|c|c|c|c|c|c|}
\hline \multirow{2}{*}{ Characters } & \multirow{2}{*}{ Mean } & \multicolumn{5}{|c|}{ Genetic components of variance } \\
\hline & & PCV (\%) & GCV $(\%)$ & $\mathrm{h}_{\mathrm{bs}}^{2}(\%)$ & GA & GAM (\%) \\
\hline Days to first flower & 69.90 & 11.930 & 11.598 & 94.523 & 16.245 & 23.229 \\
\hline Days to boll bursting & 113.70 & 5.453 & 4.924 & 81.528 & 10.414 & 9.158 \\
\hline Plant height & 167.75 & 15.042 & 10.358 & 47.419 & 24.649 & 14.693 \\
\hline $\begin{array}{l}\text { No. of } \\
\text { monopods/plant }\end{array}$ & 9.88 & 12.197 & 10.784 & 40.726 & 1.008 & 10.233 \\
\hline No. of bolls/plant & 28.84 & 20.765 & 19.216 & 85.635 & 10.567 & 36.631 \\
\hline Boll weight & 2.43 & 9.210 & 8.561 & 86.399 & 0.400 & 16.393 \\
\hline No. of seeds/boll & 24.71 & 6.777 & 5.941 & 76.865 & 2.637 & 10.730 \\
\hline GOT & 40.35 & 4.357 & 4.066 & 87.109 & 3.155 & 7.818 \\
\hline Lint index & 3.51 & 10.259 & 9.276 & 81.752 & 0.607 & 17.277 \\
\hline Seed index & 5.16 & 6.125 & 4.849 & 80.660 & 9.408 & 11.907 \\
\hline $\begin{array}{l}\text { Seed cotton yield/ } \\
\text { plant }\end{array}$ & 61.04 & 27.895 & 25.633 & 84.441 & 29.621 & 48.523 \\
\hline Lint yield/plant & 24.60 & 27.877 & 25.347 & 82.674 & 11.683 & 47.476 \\
\hline
\end{tabular}

GCV- Genotypic coefficient of variation, PCV- Phenotypic Coefficient of Variation, $\mathrm{h}_{\mathrm{b}}{ }_{\mathrm{b}}-$ heritability (broad sense), GA -Genetic advance, GAM -Genetic advance expressed as percentage of mean 
Table.3 Genotypic and phenotypic correlations of various quantitative traits

\begin{tabular}{|c|c|c|c|c|c|c|c|c|c|c|c|c|c|}
\hline \multicolumn{2}{|c|}{ Characters } & \multirow{2}{*}{$\begin{array}{l}\begin{array}{l}\text { Days } \\
\text { to } \\
\text { first } \\
\text { flower } \\
1.00\end{array} \\
\end{array}$} & \multirow{2}{*}{$\begin{array}{r}\begin{array}{l}\text { Days to } \\
\text { boll } \\
\text { bursting }\end{array} \\
0.801^{* *}\end{array}$} & \multirow{2}{*}{$\begin{array}{l}\begin{array}{l}\text { Plant } \\
\text { height }\end{array} \\
0.863^{* *} \\
\end{array}$} & \multirow{2}{*}{$\begin{array}{l}\text { No. of } \\
\text { monopods/ } \\
\text { plant } \\
0.960^{* *}\end{array}$} & \multirow{2}{*}{$\begin{array}{l}\begin{array}{l}\text { No. of } \\
\text { bolls/ } \\
\text { plant }\end{array} \\
0.623^{* *} \\
\end{array}$} & \multirow{2}{*}{\begin{tabular}{|l}
$\begin{array}{l}\text { Boll } \\
\text { weight }\end{array}$ \\
$0.644^{* *}$ \\
\end{tabular}} & \multirow{2}{*}{$\begin{array}{l}\begin{array}{l}\text { No. of } \\
\text { seeds/ } \\
\text { boll }\end{array} \\
0.658^{* *} \\
\end{array}$} & \multirow{2}{*}{$\begin{array}{r}\text { GOT } \\
0.268^{* *} \\
\end{array}$} & \multirow{2}{*}{$\begin{array}{r}\text { Lint index } \\
0.635^{* *}\end{array}$} & \multirow{2}{*}{$\begin{array}{r}\text { Seed index } \\
0.814^{* *}\end{array}$} & \multirow{2}{*}{$\begin{array}{l}\begin{array}{l}\text { Seed cotton } \\
\text { yield/ } \\
\text { plant }\end{array} \\
\qquad \quad 0.825^{\text {** }}\end{array}$} & \multirow{2}{*}{$\begin{array}{l}\begin{array}{l}\text { Lint yield/ } \\
\text { plant }\end{array} \\
0.882^{* *}\end{array}$} \\
\hline Days to & $\mathbf{G}$ & & & & & & & & & & & & \\
\hline first flower & $\mathbf{P}$ & 1.00 & $0.692^{* *}$ & $0.578^{* *}$ & $0.590^{* *}$ & $0.553^{* *}$ & $0.586^{* *}$ & $0.560^{* *}$ & $0.258^{* *}$ & $0.567^{* *}$ & $0.622^{* *}$ & $0.742^{\text {** }}$ & $0.787^{* *}$ \\
\hline \multirow{2}{*}{$\begin{array}{l}\text { Days to boll } \\
\text { bursting }\end{array}$} & $\mathbf{G}$ & & 1.00 & $1.011^{* *}$ & $0.657^{* *}$ & $0.214^{*}$ & $0.516^{* *}$ & $0.394^{* *}$ & $0.691^{* *}$ & $0.914^{* *}$ & $0.752^{* *}$ & $0.442^{* * *}$ & $0.559^{* *}$ \\
\hline & $\mathbf{P}$ & & 1.00 & $0.589^{* *}$ & $0.324^{* *}$ & $0.216^{*}$ & $0.423^{* *}$ & $0.321^{* *}$ & $0.582^{* *}$ & $0.733^{* *}$ & $0.520^{* *}$ & $0.395^{* *}$ & $0.490^{* * *}$ \\
\hline $\begin{array}{l}\text { Plant } \\
\text { height }\end{array}$ & $\mathbf{P}$ & & & 1.00 & $0.221^{*}$ & $0.252^{* *}$ & $0.264^{* *}$ & $0.216^{*}$ & $0.452^{* *}$ & $0.546^{* *}$ & $0.356^{* *}$ & $0.338^{* *}$ & $0.405^{* *}$ \\
\hline \multirow{2}{*}{$\begin{array}{l}\text { No. of } \\
\text { monopods/ } \\
\text { plant }\end{array}$} & G & & & & 1.00 & $0.656^{* *}$ & $0.830^{* *}$ & $0.996^{* *}$ & $-0.068^{\mathrm{NS}}$ & $0.422^{* *}$ & $0.913^{* *}$ & $0.870^{* *}$ & $0.867^{* *}$ \\
\hline & $\mathbf{P}$ & & & & 1.00 & $0.343^{* *}$ & $0.492^{* *}$ & $0.526^{* *}$ & $-0.059^{\mathrm{NS}}$ & $0.273^{* *}$ & $0.546^{* *}$ & $0.470^{* *}$ & $0.461^{* * *}$ \\
\hline \multirow{2}{*}{$\begin{array}{l}\text { No. of bolls/ } \\
\text { plant }\end{array}$} & $\mathbf{G}$ & & & & & 1.00 & $0.007^{\mathrm{NS}}$ & $0.341^{* * *}$ & $-0.299^{* *}$ & $-0.060^{\mathrm{NS}}$ & $0.303^{* *}$ & $0.946^{* *}$ & $0.911^{* * *}$ \\
\hline & $\mathbf{P}$ & & & & & 1.00 & $0.014^{\mathrm{NS}}$ & $0.289^{* *}$ & $-0.248^{* *}$ & $-0.050^{\mathrm{NS}}$ & $0.207^{*}$ & $0.910^{* *}$ & $0.875^{* *}$ \\
\hline Boll weight & $\mathbf{P}$ & & & & & & 1.00 & $0.692^{* *}$ & $0.090^{\mathrm{NS}}$ & $0.457^{* *}$ & $0.657^{* *}$ & $0.273^{* *}$ & $0.291^{* *}$ \\
\hline \multirow{2}{*}{$\begin{array}{l}\text { No. of } \\
\text { seeds/ } \\
\text { boll }\end{array}$} & $\mathbf{G}$ & & & & & & & 1.00 & $-0.280^{* *}$ & $0.209^{*}$ & $0.823^{* *}$ & $0.541^{* *}$ & $0.505^{* *}$ \\
\hline & $\mathbf{P}$ & & & & & & & 1.00 & $-0.169^{\mathrm{NS}}$ & $0.188^{\mathrm{NS}}$ & $0.539^{* * *}$ & $0.466^{* * *}$ & $0.442^{* *}$ \\
\hline \multirow[t]{2}{*}{ GOT } & $\mathbf{G}$ & & & & & & & & 1.00 & $0.854^{* *}$ & $0.195^{*}$ & $-0.171^{\mathrm{NS}}$ & $-0.021^{\mathrm{NS}}$ \\
\hline & $\mathbf{P}$ & & & & & & & & 1.00 & $0.799^{* *}$ & $0.129^{\mathrm{NS}}$ & $-0.124^{\mathrm{NS}}$ & $0.027^{\mathrm{NS}}$ \\
\hline \multirow[t]{2}{*}{ Lint index } & $\mathbf{G}$ & & & & & & & & & 1.00 & $0.675^{* *}$ & $0.184^{\mathrm{NS}}$ & $0.319^{* *}$ \\
\hline & $\mathbf{P}$ & & & & & & & & & 1.00 & $0.691^{* *}$ & $0.164^{\mathrm{NS}}$ & $0.288^{* *}$ \\
\hline \multirow[t]{2}{*}{ Seed index } & $\mathbf{G}$ & & & & & & & & & & 1.00 & $0.577^{* *}$ & $0.617^{* *}$ \\
\hline & $\mathbf{P}$ & & & & & & & & & & 1.00 & $0.413^{* *}$ & $0.436^{* *}$ \\
\hline \multirow{2}{*}{$\begin{array}{l}\text { Seed cotton } \\
\text { yield/ } \\
\text { plant }\end{array}$} & $\mathbf{G}$ & & & & & & & & & & & 1.00 & $0.988 * *$ \\
\hline & $\mathbf{P}$ & & & & & & & & & & & 1.00 & $0.988^{* *}$ \\
\hline $\begin{array}{l}\text { Lint yield/ } \\
\text { plant }\end{array}$ & $\mathbf{G}$ & & & & & & & & & & & & 1.00 \\
\hline
\end{tabular}


Table.4 Direct effects (diagonal) and indirect effects (off diagonal) of various quantitative traits on seed cotton yield at genotypic level

\begin{tabular}{|c|c|c|c|c|c|c|c|c|c|c|c|c|}
\hline Characters & $\begin{array}{l}\text { Days to } \\
\text { first } \\
\text { flower }\end{array}$ & $\begin{array}{l}\text { Days to } \\
\text { boll } \\
\text { bursting }\end{array}$ & $\begin{array}{l}\text { Plant } \\
\text { height }\end{array}$ & $\begin{array}{l}\text { No. of } \\
\text { monopods/ } \\
\text { plant }\end{array}$ & $\begin{array}{l}\text { No. of } \\
\text { bolls/ } \\
\text { plant }\end{array}$ & $\begin{array}{l}\text { Boll } \\
\text { weight }\end{array}$ & $\begin{array}{l}\text { No. of } \\
\text { seeds/ } \\
\text { boll }\end{array}$ & GOT & $\begin{array}{l}\text { Lint } \\
\text { index }\end{array}$ & $\begin{array}{l}\text { Seed } \\
\text { index }\end{array}$ & $\begin{array}{l}\text { Lint } \\
\text { yield/ } \\
\text { plant }\end{array}$ & $\begin{array}{l}\text { Genotypic } \\
\text { correlation } \\
\text { with seed } \\
\text { cotton yield }\end{array}$ \\
\hline $\begin{array}{l}\text { Days to } \\
\text { first flower }\end{array}$ & -0.073 & -0.037 & 0.037 & 0.000 & 0.114 & 0.054 & -0.015 & 0.047 & -0.234 & 0.181 & 0.748 & $0.825^{* *}$ \\
\hline $\begin{array}{l}\text { Days to } \\
\text { boll } \\
\text { bursting }\end{array}$ & -0.058 & -0.046 & 0.044 & 0.000 & 0.039 & 0.044 & -0.009 & 0.122 & -0.336 & 0.168 & 0.474 & $0.442^{* *}$ \\
\hline $\begin{array}{l}\text { Plant } \\
\text { height }\end{array}$ & -0.063 & -0.046 & 0.044 & 0.000 & 0.071 & 0.032 & -0.006 & 0.130 & -0.328 & 0.146 & 0.577 & $0.555^{* *}$ \\
\hline $\begin{array}{l}\text { No. of } \\
\text { monopods/ } \\
\text { plant }\end{array}$ & -0.070 & -0.030 & 0.032 & 0.000 & 0.119 & 0.070 & -0.023 & -0.012 & -0.155 & 0.204 & 0.735 & $0.870^{* *}$ \\
\hline $\begin{array}{l}\text { No. of } \\
\text { bolls/ } \\
\text { plant }\end{array}$ & -0.045 & -0.009 & 0.017 & 0.000 & 0.282 & 0.000 & -0.008 & -0.053 & 0.022 & 0.068 & 0.673 & $0.946^{* *}$ \\
\hline Boll weight & -0.047 & -0.023 & 0.016 & 0.000 & 0.001 & 0.085 & -0.019 & 0.016 & -0.195 & 0.194 & 0.294 & $0.323^{* *}$ \\
\hline $\begin{array}{l}\text { No. of } \\
\text { seeds/ } \\
\text { boll }\end{array}$ & -0.048 & -0.018 & 0.012 & 0.000 & 0.062 & 0.071 & -0.023 & -0.050 & -0.077 & 0.183 & 0.428 & $0.541^{* *}$ \\
\hline GOT & -0.019 & -0.031 & 0.032 & -0.000 & -0.054 & 0.008 & 0.006 & -0.177 & -0.137 & 0.043 & -0.018 & $-0.171^{\mathrm{NS}}$ \\
\hline Lint index & -0.046 & -0.042 & 0.039 & 0.000 & -0.011 & 0.045 & -0.005 & 0.151 & -0.368 & 0.151 & 0.271 & $0.184^{\mathrm{NS}}$ \\
\hline Seed index & -0.059 & -0.034 & 0.028 & 0.000 & 0.055 & 0.074 & -0.018 & 0.035 & -0.249 & 0.223 & 0.523 & $0.577^{* *}$ \\
\hline $\begin{array}{l}\text { Lint yield/ } \\
\text { plant }\end{array}$ & -0.064 & -0.025 & 0.029 & 0.000 & 0.166 & 0.029 & -0.011 & -0.004 & -0.117 & 0.137 & 0.848 & $0.988 * *$ \\
\hline
\end{tabular}

Residual effect 0.00046 
Fig.1 Genetic components of variance for various quantitative traits

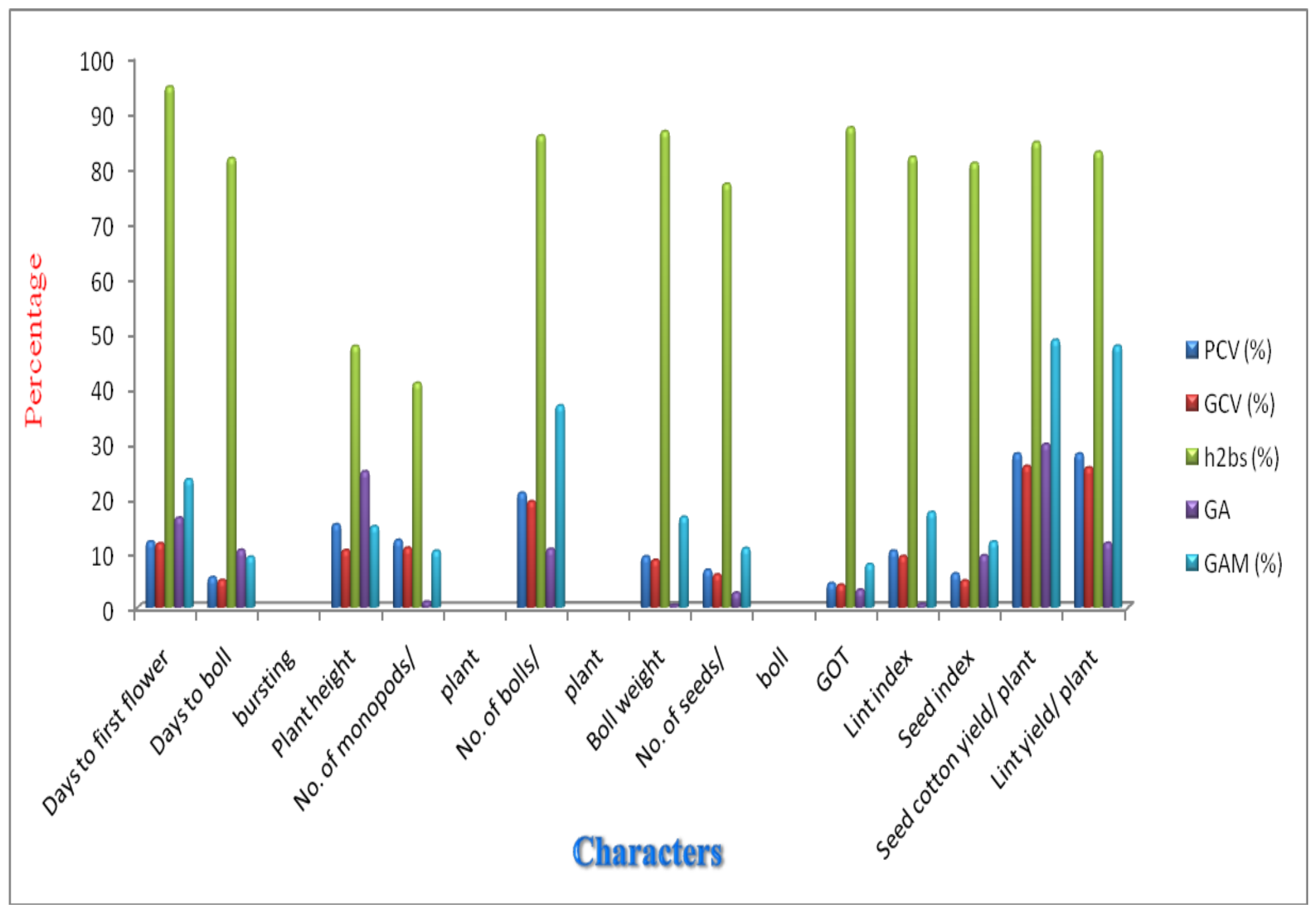


The genotypic and phenotypic correlation coefficient between yield and its components were presented in Table 3.

Seed cotton yield per plant had highly significant and positive correlation with characters viz., lint yield per plant, number of bolls per plant, boll weight, seed index, number of seeds per boll, number of monopods per plant, plant height, days to boll bursting and days to first flower. It indicated that increase in one trait will simultaneously increase in the other. Such positive association of seed cotton yield per plant with these traits was also observed by Rajamani et al., (2013), Pujer et al., (2014) and Asha et al., (2015). Seed cotton yield per plant was having non-significant association lint index and ginning out turn.

In the present study, genotypic correlation coefficient were higher than phenotypic correlation coefficient, which revealed that there was strong genetic association between these characters but the phenotypic value lessened by the significant interaction of environment.

The genotypic correlation coefficients of seed cotton yield with other yield contributing traits were further partitioned into direct and indirect effects and the results were presented in Table 4.

The component of residual effect of path analysis in yield was 0.00046 . Lint yield per plant exhibited maximum positive direct effects on seed cotton yield followed by number of bolls per plant, seed index, boll weight and plant height. Whereas negative direct effect was observed in case of lint index followed by ginning outturn, days to first flower, days to boll bursting and number of seeds per boll. Kaushik and Kapoor (2006), Pujer et al., (2014) and Asha et al., (2015) also reported the same findings.
High estimate of PCV and GCV were observed for seed cotton yield per plant, lint yield per plant and number of bolls per plant. High heritability and high genetic advance over the mean was observed in case of seed cotton yield per plant, lint yield per plant, number of bolls per plant and days to first flower. Correlation and direct and indirect effect estimates vary for different traits with variation in genetic material. Hence, these findings will be effective to formulate a sound breeding program to develop new cotton cultivars with desirable traits suitable in varying environmental conditions.

\section{References}

Al-Jibouri, HA, Miller, PA and Robinson, HF. 1958. Genotypic and environmental variances and co-variances in upland cotton crosses of interspecific origin. Agron. J., 50: 633-637.

Amudha, K, Raveenderan, TS and Krishadas, D. 1996. Path analysis in coloured linted cotton varieties. Madras Agric. J., 83: 693696.

Asha, R, Ahamed, ML, Babu, DR and Kumar, PA. 2015. Character association and path coefficient analysis for yield and component traits in upland cotton. J. Cotton Res. and Dev., 29 (1): 31-35.

Basal, H and Turgut, I. 2005. Genetic analysis of yield components and fiber strength in Upland cotton (G. hirsutum L.). Asian J. Plant Sci., 4(3): 293-298.

Basbag, S. and Gencer, O. 2004. Investigations on the heritability of seed cotton yield, yield components and technological characters in cotton (G. hirsutum L.). Pak. J. Biol. Sci., 7(8): 1390-1393

Burton, GW and DeVane, EW. 1953. Estimating heritability in tall fescue (Feetuca circuhinoceae) from replicated clonal material. Agron. J., 45: 478-481.

Dewey, DR and Lu, KH. 1959. A correlation and path coefficient analysis of components of crested wheat grass seed Production. Agron. J., 51: 515-518.

Dhamayanathi, KPM, Manickam S, and 
Rathinavel, K. 2010. Genetic variability studies in Gossypium barbadense L. genotypes for seed cotton yield and its yield components. Electronic J. Pl. Breed., 1(4): 961-965.

Gite, VK, Misal, MB and Kalpande, HV. 2006. Correlation and path analysis in cotton (Gossypium hirsutum L.). J. Cotton Res. Dev., 20: 51-54.

Gururajan, KN and Sunder, S. 2004. Yield component analysis in American cotton (Gossypium barbadense L.). In: International Symposium on Strategies for Sustainable Cotton Production-A Global Vision. Crop Improvement. J. Indian Soc. Cotton Improv., 25: 17-22.

Hanson, $\mathrm{CH}$, Robinson, $\mathrm{HF}$ and Comstock, RE. 1956. Biometrical studies of yield and segregating populations of Korean lespedza. Agron. J., 47: 313-318.

Johanson, HW, Robinson, $\mathrm{H}$ and Comstock, RE. 1955. Estimates of genetic and environmental variability in soybean. Agron. J., 47: 314 - 318.

Joshi, HJ, Chovatia, PK and Metha, DR. 2006. Genetic variability, character association and component analysis in upland cotton. Indian J. Agric. Res., 40: $302-305$.

Kaushik, SK and Kapoor, CJ. 2006. Genetic variability and association study for yield and its component traits in upland cotton (Gossypium hirsutum L.). J. Cotton Res. and Dev., 20 (2): 185-190.

Kaushik, SK, Kapoor, CJ and Koli, NR. 2003. Association and path analysis in American cotton (Gossypium hirsutum L.). J. Cotton. Res. Dev., 17: 24-26.

Khurram Tausif and Patil SS. 2009. Genetic studies on improving productivity and quality traits involving interspecific $(\mathrm{H} \mathrm{x} \mathrm{B})$ crosses and barbadense genotypes. J. Agric. Sci., 22(5): 275-295.

Kulkarni, AA, Nanda, HC and Patil, SG. 2011. Studies on genetic divergence in upland cotton (Gossypium hirsutum L.). J. cotton Res. Dev., 25(1): 9-13.

Neelama, GD and Potdukhe, NR. 2002. Studies on variability and correlations in upland cotton for yield and its components. $J$. Indian Soc. Cotton Improv., 27(3): 148-152.

Patnaik, RK and Sial, P. 2010. Genetic variability, character association and component analysis in upland cotton (Gossypium hirsutum L.) under rainfed condition. $J$. Cotton Res. Dev., 24 (2): 155-159.

Pujer, SK, Siwach, SS, Sangwan, RS, Sangwan, O and Deshmukh, J. 2014. Correlation and path coefficient analysis for yield and fibre quality traits in upland cotton (Gossypium hirsutum L.). J. Cotton Res. and Dev., 28 (2): 214-216.

Rajamani, S, Sumalatha, P and Gopinath, M. 2013. Correlation and path coefficient analysis in upland cotton (Gossypium hirsutum L.). J. Cotton Res and Dev., 27 (2), 188-190.

Rao, GN, Reddy, MSS and Shanthi, P. 2001. Correlation and path analysis of seed cotton yield and its components in cotton. $J$. Cotton Res. Dev., 15: 81-83.

Sambamurthy, JSV, Reddy, DM and Reddy, KHG. 1995. Genetic variability, correlation and path analysis in cotton. J. Indian Soc. Cotton Improv, 20: 133-137.

Sambamurthy, JSV and Rao, BR. 1998. Genetic variability and association analysis in parents and hybrids of American cotton. J. Cotton Res. Dev., 12: 236-241.

\section{How to cite this article:}

Sunayana, R.S. Sangwan and Somveer Nimbal. 2017. Studies on Association, Path Analysis and Genetic Parameters for Seed Cotton Yield and Its Contributing Characters in Desi Cotton (Gossypium arboreum L.). Int.J.Curr.Microbiol.App.Sci. 6(11): 104-111. doi: https://doi.org/10.20546/ijcmas.2017.611.013 